\title{
Possible impacts of volcanic ash emissions of Mount Etna on the primary productivity in the oligotrophic Mediterranean Sea: Results from nutrient-release experiments in seawater
}

\author{
Nazlı Olgun a,b,*, Svend Duggen ${ }^{\mathrm{a}, \mathrm{c}}$, Daniele Andronico ${ }^{\mathrm{d}}$, Steffen Kutterolf ${ }^{\mathrm{a}}$, Peter Leslie Croot ${ }^{\mathrm{b}, \mathrm{e}}$, \\ Salvatore Giammanco ${ }^{\mathrm{d}}$, Paolo Censi ${ }^{\mathrm{f}}$, Loredana Randazzo ${ }^{\mathrm{f}}$ \\ a Dynamics of the Ocean Floor Division, Helmholtz-Center for Ocean Research, GEOMAR, Kiel, Germany \\ ${ }^{\mathrm{b}}$ Marine Biogeochemistry Division, Helmholtz-Center for Ocean Research, GEOMAR, Kiel, Germany \\ c A. P. Møller Skolen Upper Secondary School and Sixth Form College of the Danish National Minority in Germany, Schleswig, Germany \\ d Istituto Nazionale di Geofisica e Vulcanologia, Sezione di Catania, Osservatorio Etneo, Piazza Roma 2, Catania 95123, Italy \\ e Earth and Ocean Sciences Department, National University of Ireland, Galway, Ireland \\ ${ }^{\mathrm{f}}$ Dipartimento di Scienze della Terra e del Mare (DiSTeM), Università di Palermo, Via Archirafi, 3690123 Palermo, Italy
}

\section{A R T I C L E I N F O}

\section{Article history:}

Received 6 February 2012

Received in revised form 5 April 2013

Accepted 10 April 2013

Available online 24 April 2013

\section{Keywords:}

Oceanic fertilization

Volcanic ash

Mount Etna

Mediterranean Sea

Phosphate

Nitrate

Iron

\begin{abstract}
A B S T R A C T
Atmospheric deposition of volcanic ash has recently been recognized as an important nutrient source into the surface ocean. Mount Etna (Italy), one of the world's most active volcanoes, is located in the oligotrophic Mediterranean Sea (MedSea). Despite the active volcanism on Mount Etna, the biogeochemical impacts of volcanic ash fallouts on the marine primary productivity (MPP) remain largely unknown. Here we present the results of seawater nutrient release experiments with volcanic ash samples from Mount Etna that have been collected during different eruptive episodes between 2001 and 2007. Our results show that volcanic ash from Mount Etna releases significant amounts of fixed-N (35-855 nmol/g), P (7-970 nmol/g), Si (3-2060 nmol/g), Fe (10-130 nmol/g) and $\mathrm{Zn}(<21 \mathrm{nmol} / \mathrm{g})$. We further estimated an example representative of ash-fall from Etna based on the case-study focusing on 4-5 November 2002 activity, by using the general relation between the thicknesses of the ash deposits and the ash depositional areas. Etna explosive eruptions can transport volcanic ash as far as $800 \mathrm{~km}$, with ash emissions exceeding the particle flux during dust storm events (of $10 \mathrm{~g} / \mathrm{m}^{2}$ input) as far as $400 \mathrm{~km}$ downwind from the volcano. Our results emphasize that Etna ash can provide a significant supply of nutrients, which can favor the MPP in the central MedSea.

(c) 2013 Elsevier B.V. All rights reserved.
\end{abstract}

\section{Introduction}

Volcanic ash ejected from various subduction zones and hotspot volcanic eruptions rapidly mobilizes an array of biologically relevant elements into the seawater, which can affect the marine primary productivity (MPP) in the photic zone of the water column (Duggen et al., 2007; Frogner et al., 2001; Jones and Gislason, 2008; Olgun et al., 2011). Bio-incubation experiments with volcanic ash showed that the nutrients released from ash are bioavailable for the phytoplankton and utilized for reproduction (Duggen et al., 2007; Hoffmann et al., 2012). Oceanic fertilization by volcanic eruptions has been further evidenced by massive phytoplankton blooms in the ash fallout areas in the Fe-limited regions (Hamme et al., 2010; Langmann et al., 2010) and oligotrophic ocean regions (Lin et al., 2011; Uematsu et al., 2004).

\footnotetext{
* Corresponding author at: Eurasia Institute of Earth Sciences, Istanbul Technical University, Istanbul, Turkey. Tel.: +90 2122857437; fax: +90 2856080.

E-mail address: nazliolgun.kiyak@itu.edu.tr (N. Olgun).
}

Mediterranean Sea (MedSea), although a nearly-enclosed basin, is a low-nutrient and low-chlorophyll (LNLC) region characterized by very low nutrient levels (like the open ocean gyres) during the stratification period in summer and autumn (Bethoux et al., 1998; Bonnet et al., 2005; Moutin and Raimbault, 2002). External supply of nutrients through atmospheric deposition plays an important role on the MPP in the MedSea (Guerzoni et al., 1999; Krom et al., 1991; Markaki et al., 2003). Large amounts of desert dust $\left(20-50 \times 10^{12} \mathrm{~g} / \mathrm{y}\right)$ originating from adjacent arid regions in North Africa and Middle East are deposited into the MedSea (Guerzoni et al., 1999).

Mount Etna, located on the island of Sicily (Italy) in the central MedSea, is the biggest volcano in Europe and one of the most active world-wide (Fig. 1). Recent in situ seawater measurements within the volcanic ash fallout region of Mount Etna showed that the chlorophyll-a concentrations significantly (two to three folds) increased in the ash fallout regions in the MedSea (Censi et al., 2010). Volcanic ash plumes generated by Mount Etna are transported by the wind hundreds of kilometers over the MedSea reaching as far as Greece and Libya (Figs. 1 and 3) (Andronico et al., 2008b; Dellino and Kyriakopoulos, 2003; Kelepertsis et al., 2003). Tephra ejected in some of the eruptions was in 
a)

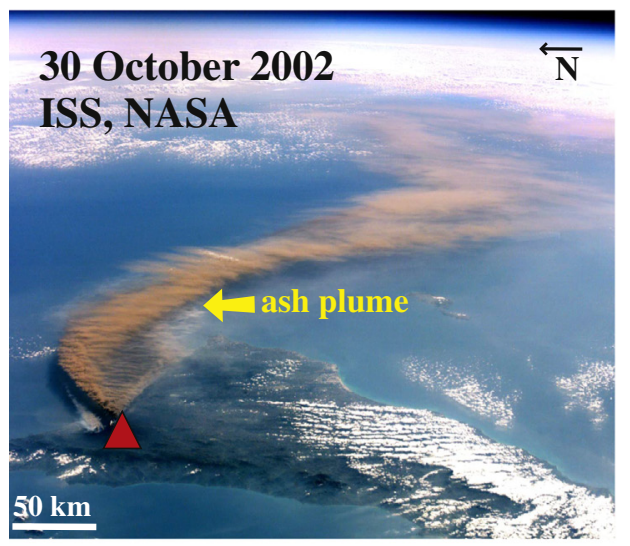

c)

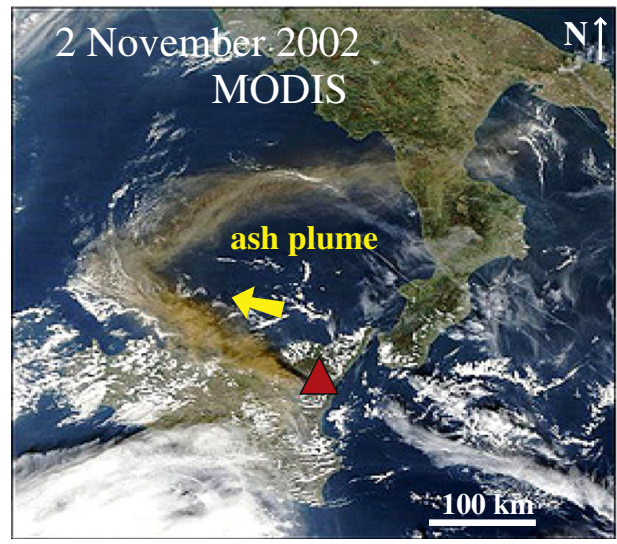

b)

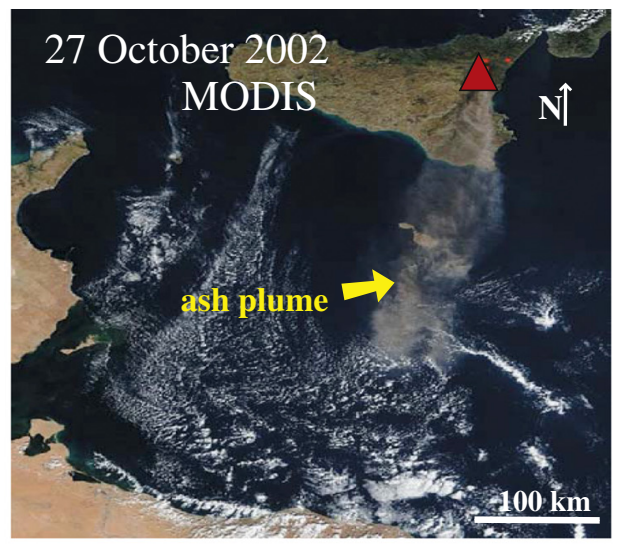

d)

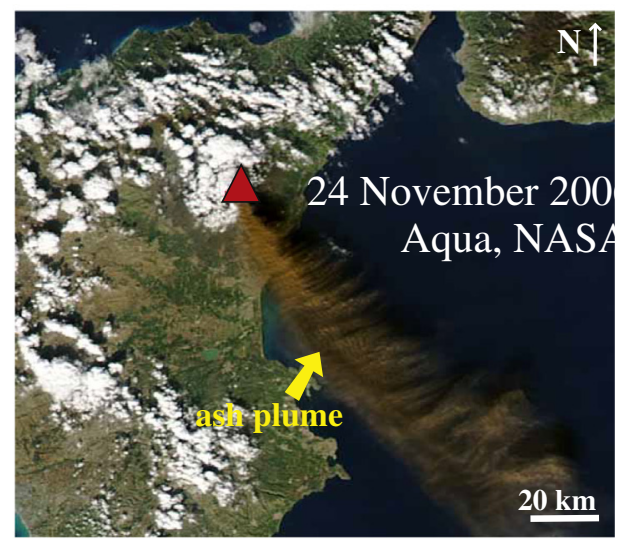

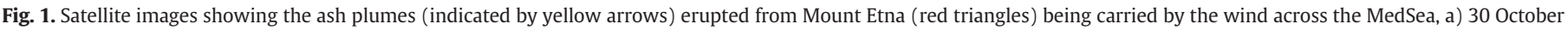

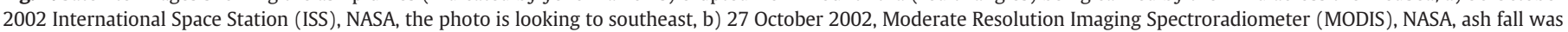

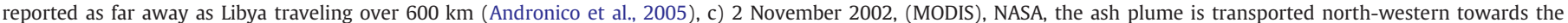

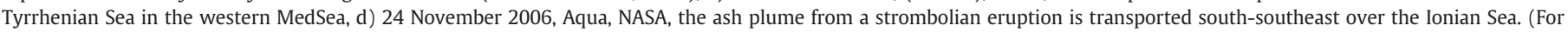
interpretation of the references to color in this figure legend, the reader is referred to the web version of this article.)

amounts as high as the yearly dust input in the MedSea (e.g., 2002-03 eruption ejected $38-50 \times 10^{12} \mathrm{~g}$ ash) (Andronico et al., 2008b). However, despite the increasing explosivity and the large input of volcanic ash from Mount Etna, the biogeochemical impacts of Etna ash on the nutrient-starved MedSea remain largely unknown.

In this study, we performed nutrient-release experiments in seawater with volcanic ash samples from Mount Etna and a loess sample consisting of dust originated from Sahara desert. We analyzed release of fixed-N $\left(\mathrm{NO}_{3}^{-}, \mathrm{NH}_{4}^{+}, \mathrm{NO}_{2}^{-}\right), \mathrm{P}, \mathrm{Si}$ and trace metals $\mathrm{Fe}, \mathrm{Zn}$ and $\mathrm{Cu}$. We further constrained the propagation of ash flux in the MedSea downwind of the eruption plume during an explosive eruption of Etna, based on 4 November 2002 eruption as a case study. Finally, our analysis/research allowed us to evaluate the possible nutrient supply and the eventual biogeochemical impacts of the volcanic ash deposition in the MedSea during explosive eruptions of Etna.

\section{Samples and methods}

\subsection{Volcanic ash and mineral dust sample(s)}

We have analyzed the seawater-nutrient release of thirteen Etna ash samples and one loess sample from Cape Verde Island. Etna ash samples used in this study were ejected from eruptions covering a range in the years $2001(\mathrm{n}=3), 2002(\mathrm{n}=4), 2004(\mathrm{n}=1), 2005$ $(\mathrm{n}=1), 2006(\mathrm{n}=2)$ and $2007(\mathrm{n}=2)$ (Table 1$)$. The ash samples were collected within few hours after the deposition by the scientific team lead by Dr. Danielle Andronico. The sampling sites have been previously selected around Etna based on the presence of more appropriate smooth and flat surfaces, thus permitting to collect the tephra deposit over a measured area (Andronico et al., 2009a,b). Ash samples were then archived in the Sedimentology Laboratory at INGV-CT. The ash samples used were composed of dry ash that had not been in contact with water after deposition (pristine ash). The samples had not been in contact with any metal containing equipment (e.g., sieves). Most of the samples consist of ash particles (i.e. $<2 \mathrm{~mm}$ in size), especially when the fallout deposit exceeds several $\mathrm{km}$ from the vents.

A description of the samples is shown in Table 1. For the purposes of this paper we subdivide the eruptions into a) episodic, during which the explosive activity lasted from a few minutes to several hours, b) long-lasting, when we observe a continuous ash emission lasting several days, as occurred during the 2001 and 2002-03 eruptions, and c) lava fountain, when the ash is produced during lava fountain episodes. Due to limitations in the sample quantity, four ash samples were selected for macronutrient measurements for twenty-hour contact with seawater. Six ash samples were selected for bulk element content and volcanic glass composition determination.

The loess sample from Cape Verde Island simulates a Saharan aerosol. The same loess sample was used previously in Olgun et al., 2011 and Heller and Croot, 2011. This sample was collected from loess deposits from the northeastern corner of the island of Sao Vicente $\left(16.9^{\circ} \mathrm{N}\right.$, 
a) Phosphate

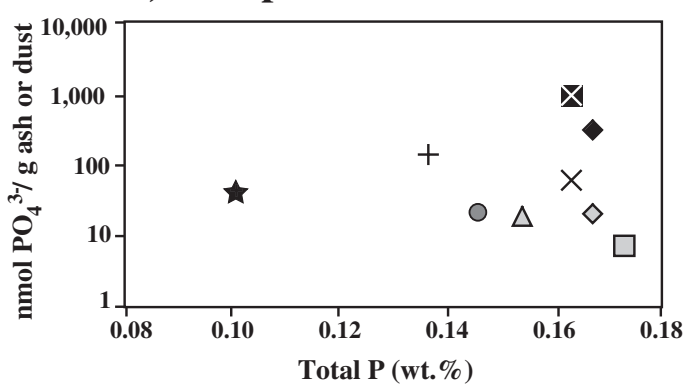

c) Iron

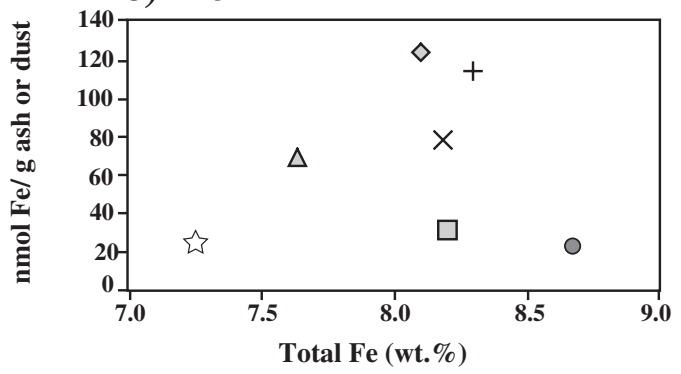

b) Silica

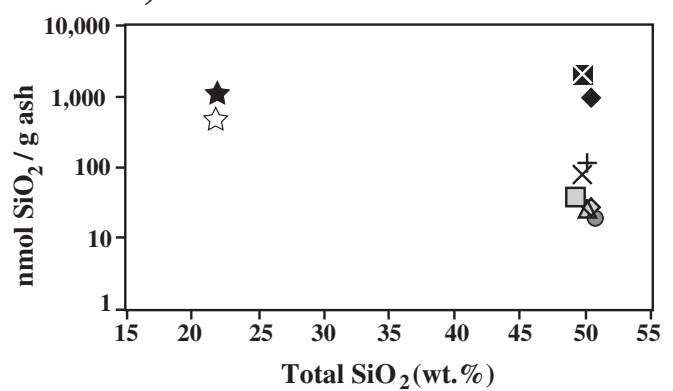

d) Zinc

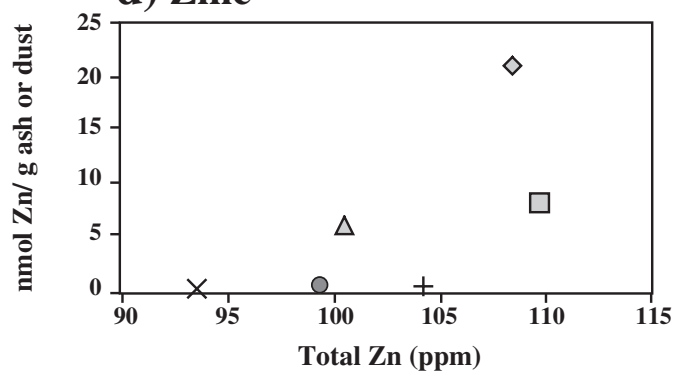

LEGEND

\begin{tabular}{|ll|}
\hline $\begin{array}{l}\text { One hour dissolution } \\
\text { in seawater }\end{array}$ & $\Delta$ Et-2001b $\bigcirc$ Et-2002c $\times$ Et-2004 + Et-2005 \\
$\begin{array}{l}\text { Twenty hours dissolution } \\
\text { in seawater }\end{array}$ & $\nabla$ Et-2006b $\square$ Et-2007b $\lesssim$ Cape Verde Loess \\
\hline
\end{tabular}

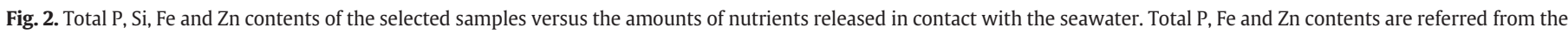

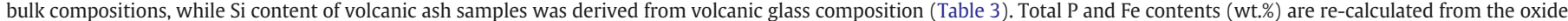

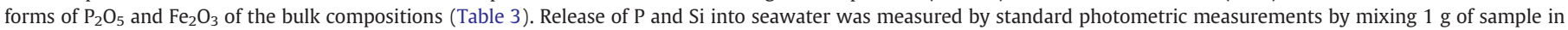
$50 \mathrm{ml}$ seawater (Table 2). Release of Fe and $\mathrm{Zn}$ was measured by means of voltametric measurements by mixing $50 \mathrm{mg}$ sample with $20 \mathrm{ml}$ seawater (Table 2 ).

$24.9^{\circ} \mathrm{W}$ ) in the Cape Verdean archipelago that are composed of aerosols transported from North African deserts and described as 80-95\% Saharan origin (Heller and Croot, 2011). The loess sample was collected from ground and sieved through $100 \mu \mathrm{m}$ plastic filters. As we used samples that were collected from ground (soil versus aerosols), higher grain-size used may affect the nutrient release behavior of our dust sample compared to the actual potential of the long-ranged transported aerosols that deposit in the remote ocean.

\subsection{Analytical methods}

The release of $\mathrm{NO}_{3}^{-}, \mathrm{NH}_{4}^{+}, \mathrm{NO}_{2}^{-}, \mathrm{P}$ and $\mathrm{Si}$ was examined by means of leaching experiments. Natural surface seawater used in the experiments was collected from the eastern equatorial Atlantic during the Meteor cruise M68-3. One gram of volcanic ash samples was mixed with $50 \mathrm{ml}$ Atlantic seawater in $60 \mathrm{ml}$ Nalgene polypropylene (PP) plastic bottles and the mixtures were shaken gently during the initial $20 \mathrm{~min}$. A set of experiments (for nine volcanic ash samples) was conducted for one-hour contact time and another set of measurements (for four ash samples) were conducted for one-hour and also for twenty-hour contact time of ash and seawater (Table 2). Prior to the concentration measurements, the solutions were filtered through a $5 \mu \mathrm{m}$ mesh PTFE filter (Sartorius). Seawater concentrations of macronutrients were measured by standard routine photometry at GEOMAR. Measurements with dust sample were done by using the same methodology applied for the volcanic ash samples in order to allow direct comparison. The measured concentrations of dissolved macronutrients were converted to nanomoles per $\mathrm{g}$ of ash and dust ( $\mathrm{nmol} / \mathrm{g}$ ash, $\mathrm{nmol} / \mathrm{g}$ dust).
Trace-metal release experiments ( $\mathrm{Fe}, \mathrm{Zn}$ and $\mathrm{Cu}$ ) were performed by voltammetric analyses using a hanging mercury drop electrode (a Metrohm VA757 at GEOMAR) in situ in natural eastern equatorial Atlantic seawater (collected during Meteor M68-3 cruise) for one-hour contact time of ash and seawater. The natural seawater was buffered at pH 8.0 by using $200 \mu \mathrm{l}$ EPPS pH-buffer at the clean-laboratory. The $\mathrm{pH}$ chosen for our experiments directly mimics the dissolution of nutrients in the seawater through dry deposition process. Strict dry deposition is a highly effective mechanism of dust deposition in MedSea, e.g., up to $56 \%$ in the eastern MedSea increasing up to 93\% in summer (Bonnet and Guieu, 2004; Kubilay et al., 2000).

Fe-release measurements were performed using Cathodic Stripping Voltammetry with the same method used previously by Duggen et al. (2007) and Olgun et al. (2011). An artificial Fe-binding organic ligand ( $20 \mu \mathrm{l}$ of TAC) was added in the seawater before the Fe-solubility measurements (Croot and Johansson, 2000). Dissolution of $\mathrm{Zn}$ and $\mathrm{Cu}$ was measured by means of Anodic Stripping Voltammetry (Duggen et al., 2007). A known quantity of ash ( $50 \mathrm{mg}$ ) was added to the prepared $20 \mathrm{ml}$ seawater and an ash/seawater ratio of $\sim 1 / 400$ was obtained, which mimics the deposition of a $\mathrm{cm}$ - to $\mathrm{mm}$-scale ash layer onto the sea surface (Duggen et al., 2007; Olgun et al., 2011). For mineral dust, the mixing is representative for the concentration dust in rain during Sahara dust events (Ridame and Guieu, 2002). The precision of the voltammetric measurements was calculated from replicates. The deviation in the measurements, probably resulting from particle-size heterogeneity in the sub-samples, ranges between 8 and $20 \%$ for Fe- and $<1-7 \%$ for Zn-measurements (Et-2001b n $=3$; Et-2002c $\mathrm{n}=2$; Et-2005 n = 2). 


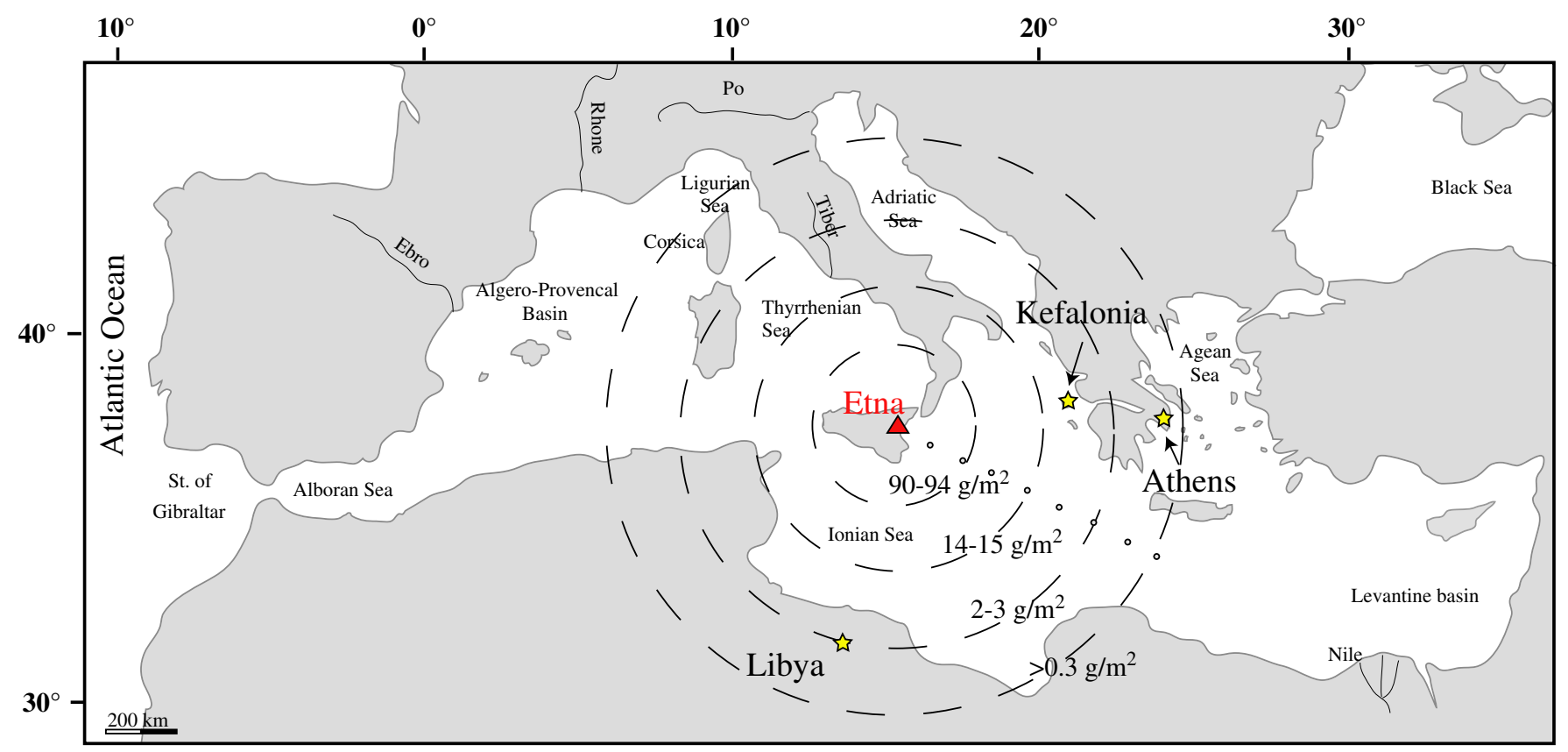

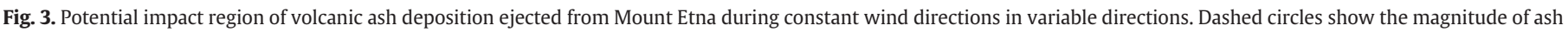

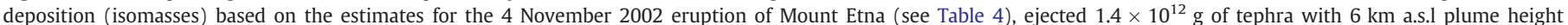

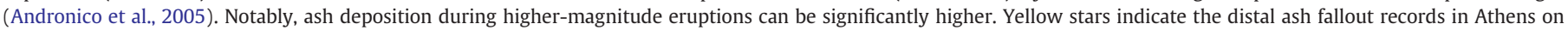

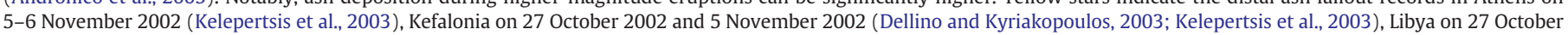

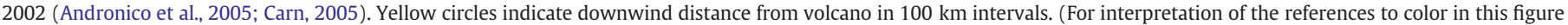
legend, the reader is referred to the web version of this article.)

Six Etna ash samples were selected (Table 3) for the major elemental compositions of glass shards and matrix glass that were determined by electron microprobe analysis (JEOL-JXA-8200). For the measurements, a fraction of the ash samples $(\sim 10 \mathrm{mg})$ were separated and sieved with de-ionized water to the size fraction 32-125 $\mu \mathrm{m}$ using de-ionized water. The ash particles were mounted on a tray with resin and analyzed with a beam current of $6 \mathrm{nA}$ and a beam size of $5 \mu \mathrm{m}$. The average glass composition was inferred from $\sim 25$ individual measurements.

Bulk (total) Fe-contents of the six selected Etna ash samples and the loess sample were determined by inductively coupled plasma spectrometry at the Institute of Geosciences, CAU University of Kiel. Approximately $100 \mathrm{mg}$ of ash and the dust sample(s) was weighed into perfluoralkoxy (PFA) vials and digested using a multi-step table-top procedure with hydrofluoric acid, aqua regia, and perchloric acid. Fe-content (in wt.\%) was determined by inductively coupled plasma-optical emission spectrometry (ICP-OES) using a Spectro Ciros SOP instrument. $\mathrm{SiO}_{2}$ content

Table 1

Description of the Etna ash samples.

\begin{tabular}{|c|c|c|c|}
\hline $\begin{array}{l}\text { Sample } \\
\text { name }\end{array}$ & Eruption date & $\begin{array}{l}\text { Plume } \\
\text { direction }\end{array}$ & Eruption style (and duration) \\
\hline Et-2001a & 28 June 2001 & SE & $\begin{array}{l}\text { Episodic ash emission (strombolian) } \\
(<3 \mathrm{~h})\end{array}$ \\
\hline Et-2001b & 22 July 2001 & E to SE & Long lasting ash emission (days) \\
\hline Et-2001c & 03 August 2001 & E to SE & Episodic ash emission (days) \\
\hline Et-2002a & 29 October 2002 & SSE & Long lasting ash emission (days) \\
\hline Et-2002b & 30 October 2002 & SSE & Long lasting ash emission (days) \\
\hline Et-2002c & 3 November 2002 & SE & Long lasting ash emission (days) \\
\hline Et-2002d & 2 December 2002 & $\mathrm{~S}$ & Long lasting ash emission (days) \\
\hline Et-2004 & 17 November 2004 & $\mathrm{~S}$ & $\begin{array}{l}\text { Episodic ash emission (tens of } \\
\text { minutes) }\end{array}$ \\
\hline Et-2005 & 8 January 2005 & SW & Episodic ash emission $(3<\mathrm{x}<6 \mathrm{~h})$ \\
\hline Et-2006a & 29 October 2006 & $\mathrm{~S}$ & Episodic ash emission (minutes) \\
\hline Et-2006b & 21 November 2006 & $\mathrm{E}$ & $\begin{array}{l}\text { Episodic ash emission (strombolian) } \\
(3<\mathrm{x}<6 \mathrm{~h})\end{array}$ \\
\hline Et-2007a & 11 April 2007 & SE & Lava fountain episodes $(<3 \mathrm{~h})$ \\
\hline Et-2007b & 23 November 2007 & $\mathrm{NE}$ & Lava fountain episodes $(6<\mathrm{x}<10 \mathrm{~h})$ \\
\hline
\end{tabular}

of the Saharan loess sample was referred from the lithium tetraborate fusion analyses (digestion with $0.5 \%$ tartaric acid and $4 \%$ nitric acid) in ITS Testing Services (UK). Concentrations were measured by ICP-OES analyses.

$\mathrm{Zn}$ and $\mathrm{Cu}$ contents (in ppm) of the digest solutions were performed by ICP-mass spectrometry (ICP-MS) using an Agilent 7500cs instrument. Analytical quality routines involved the preparation and analysis of procedural blanks, sample duplicates, and international certified reference materials BHVO-2, JR-1, and BR measured as unknowns. Analytical error as estimated from replicate measurements was better than $2 \%$ RSD for $\mathrm{Zn}, \mathrm{Cu}$, and below $1 \%$ RSD for Fe. Details of analytical procedures can be found in Garbe-Schönberg (1993).

\section{Results}

\subsection{Volcanic ash from Mount Etna}

Etna ash samples released variable amounts of fixed-N, along with $\mathrm{P}$ and $\mathrm{Si}$ (Table 2). Fixed-N mobilized from volcanic ash (and Cape Verde loess) was primarily nitrate ( $>75 \%$ ) (Table 2 ). Within the one-hour of contact with seawater, Etna ash samples released $35-855 \mathrm{nmol} / \mathrm{g}$ of total fixed-N, 7-140 nmol/g of P, and 3-790 nmol/g of Si (Table 2). At the end of twenty hour agitation, the four-selected ash samples released about $250-970 \mathrm{nmol} / \mathrm{g}$ of total fixed-N, $10-970 \mathrm{nmol} / \mathrm{g}$ of $\mathrm{P}$, and $90-$ $2060 \mathrm{nmol} / \mathrm{g}$ of Si. Each $\mathrm{g}$ of ash liberated $10-130 \mathrm{nmol} / \mathrm{g}$ of $\mathrm{Fe}$, and $<0.1-30 \mathrm{nmol} / \mathrm{g}$ of $\mathrm{Zn}$ within the 60 minute contact with seawater (Table 2). Etna ash samples did not mobilize detectable amounts of $\mathrm{Cu}$. Time dependent trace-metal release showed similar trends in relatively higher mobilization within 20 min (Table 2).

Mobilization of P and Si from Etna ash was relatively higher compared to the volcanic ash from subduction zone volcanoes (10-100 nmol/g of P, and 50-200 nmol/g of Si; (Duggen et al., 2007)). Release of fixed-N, Fe, and $\mathrm{Zn}$ is within the range found in the previous voltametric measurements at $\mathrm{pH} 8(\sim 250-1150 \mathrm{nmol} / \mathrm{g}$ of $\mathrm{N}, 35-340 \mathrm{nmol} / \mathrm{g}$ of Fe, 2-27 nmol/g of Zn; (Duggen et al., 2010; Olgun et al., 2011)). Unlike 
Table 2

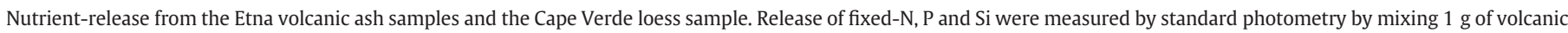

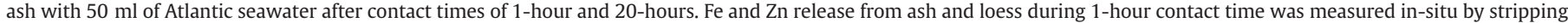
Voltammetry by mixing $50 \mathrm{mg}$ of volcanic ash with $20 \mathrm{ml}$ Atlantic seawater buffered at $\mathrm{pH}$. The results are expressed as nutrient release in nanomoles per g of ash or dust.

\begin{tabular}{|c|c|c|c|c|c|c|c|c|c|}
\hline Sample name & Contact time in seawater & Total fixed-N (nmol/g) & $\mathrm{NO}_{3}^{-}(\mathrm{nmol} / \mathrm{g})$ & $\mathrm{NH}_{4}^{+}(\mathrm{nmol} / \mathrm{g})$ & $\mathrm{NO}_{2}^{-}(\mathrm{nmol} / \mathrm{g})$ & $\mathrm{P}(\mathrm{nmol} / \mathrm{g})$ & $\mathrm{Si}(\mathrm{nmol} / \mathrm{g})$ & $\mathrm{Fe}(\mathrm{nmol} / \mathrm{g})$ & $\mathrm{Zn}(\mathrm{nmol} / \mathrm{g})$ \\
\hline Et-2001a & 1-hour & 470 & 419 & 50 & 1 & 25 & 26 & 51 & 1.0 \\
\hline Et-2001a & 20-hours & 315 & 255 & 60 & 0 & 14 & 89 & No data & No data \\
\hline Et-2001b & 1-hour & 478 & 387 & 90 & 1 & 18 & 19 & 69 & 6.0 \\
\hline Et-2001c & 1-hour & 855 & 835 & 20 & 1 & 18 & 3 & 41 & 4.0 \\
\hline Et-2002a & 1-hour & 158 & 149 & 7 & 2 & 13 & 4 & 30 & 0.0 \\
\hline Et-2002b & 1-hour & 88 & 86 & 1 & 1 & 17 & 3 & 11 & 0.0 \\
\hline Et-2002b & 20-hours & 169 & 90 & 53 & 27 & 186 & 1173 & No data & No data \\
\hline Et-2002c & 1-hour & 149 & 144 & 3 & 2 & 21 & 20 & 23 & 0.4 \\
\hline Et-2002d & 1-hour & 49 & 37 & 9 & 3 & 28 & 37 & 28 & 0.7 \\
\hline Et-2004 & 1-hour & 35 & 7 & 27 & 2 & 59 & 266 & 78 & 0.0 \\
\hline Et-2004 & 20-hours & 520 & 82 & 303 & 136 & 970 & 2058 & No data & No data \\
\hline Et-2005 & 1-hour & 65 & 19 & 45 & 2 & 137 & 793 & 114 & 0.2 \\
\hline Et-2006a & 1-hour & 627 & 570 & 55 & 3 & 125 & 127 & 130 & 12.9 \\
\hline Et-2006b & 1-hour & 493 & 324 & 169 & 1 & 20 & 27 & 124 & 21.2 \\
\hline Et-2006b & 20-hours & 527 & 277 & 174 & 76 & 310 & 949 & No data & No data \\
\hline Et-2007a & 1-hour & 222 & 136 & 86 & 1 & 26 & 69 & 26 & 1.6 \\
\hline Et-2007b & 1-hour & 86 & 44 & 41 & 1 & 7 & 39 & 32 & 8.2 \\
\hline Loess & 1-hour & 409 & 312 & 92 & 5 & 43 & 450 & $20-30$ & 0 \\
\hline Loess & 20-hours & 492 & 385 & 99 & 8 & 43 & 1110 & No data & No data \\
\hline
\end{tabular}

some of the subduction zone volcanic ash samples (releasing up to $50 \mathrm{nmol} / \mathrm{g}$ of $\mathrm{Cu}$ (Duggen et al., 2007)), Etna ash released no $\mathrm{Cu}$ into the seawater.

The major and trace element contents (except for $\mathrm{N}$ ) of the bulk ash and the volcanic glass are shown in Table 3 and Fig. 2. Bulk phosphorus contents, re-calculated from $\mathrm{P}_{2} \mathrm{O}_{5}$, are 0.1-0.2 wt.\%, with similar phosphorus contents found for volcanic glasses $0.2-0.3 \mathrm{wt} . \%$. $\mathrm{SiO}_{2}$-contents of the volcanic glasses do not vary much ranging from 49 to 50 wt.\%. Fe-contents of Etna ash are 7-8 wt.\%, re-calculated from oxide forms $\mathrm{Fe}_{2} \mathrm{O}_{3}$ for bulk and $\mathrm{FeO}$ for volcanic glass. Variation of Fe-content of the bulk ash and the volcanic glass is relatively small $(<1 \% \mathrm{Fe})$, indicating that the glass compositions likely dominate the total Fe-content of the samples (Table 3). $\mathrm{Zn}$ and $\mathrm{Cu}$ content of the bulk ash samples ranges between 100-110 ppm, and 110-160 ppm, respectively.

\subsection{Cape Verde loess}

Cape Verde loess sample released $536 \mathrm{nmol} / \mathrm{g}$ of total fixed-N (expressed as nitrate), $43 \mathrm{nmol} / \mathrm{g}$ of $\mathrm{P}$, and $450 \mathrm{nmol} / \mathrm{g}$ of Si within one-hour contact with seawater. After twenty hour contact with seawater, loess sample released $630 \mathrm{nmol} / \mathrm{g}$ of total fixed-N, $43 \mathrm{nmol} / \mathrm{g}$ of $\mathrm{P}$, and $1110 \mathrm{nmol} / \mathrm{g}$ of Si (Table 2). P-release from Cape Verdean loess did not increase during twenty hour experiment, while other nutrients showed higher mobilization rates. Fe-release of the loess sample is $20-30 \mathrm{nmol} / \mathrm{g}$ of Fe referred from Olgun et al. (2011). The

Table 3

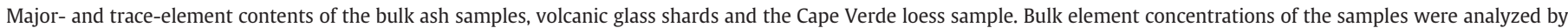

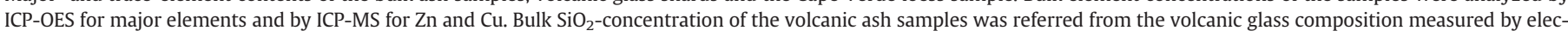
tron microprobe analyses.

\begin{tabular}{|c|c|c|c|c|c|c|c|c|}
\hline \multicolumn{2}{|c|}{ Major element oxides (wt.\%) } & \multirow{2}{*}{$\frac{\text { Et-2001b }}{50.2}$} & \multirow{2}{*}{$\frac{\text { Et-2002c }}{50.7}$} & \multirow{2}{*}{$\frac{\text { Et-2004 }}{49.8}$} & \multirow{2}{*}{$\frac{\text { Et-2005 }}{50.1}$} & \multirow{2}{*}{$\frac{\text { Et-2006b }}{50.5}$} & \multirow{2}{*}{$\frac{\text { Et-2007b }}{49.2}$} & \multirow{2}{*}{$\begin{array}{l}\text { Loess } \\
21.8\end{array}$} \\
\hline $\mathrm{SiO}_{2}$ & & & & & & & & \\
\hline \multirow[t]{2}{*}{$\mathrm{Al}_{2} \mathrm{O}_{3}$} & Bulk & 17.6 & 17.1 & 16.8 & 16.8 & 17.1 & 17.5 & 6.6 \\
\hline & Glass & 16.6 & 16.5 & 16.8 & 16.6 & 16.3 & 16.2 & - \\
\hline \multirow[t]{2}{*}{$\mathrm{Fe}_{2} \mathrm{O}_{3}$} & Bulk $\left(\mathrm{Fe}_{2} \mathrm{O}_{3}\right)$ & 9.8 & 11.2 & 10.5 & 10.7 & 10.4 & 10.5 & 9.3 \\
\hline & Glass (FeO) & 10.6 & 10.4 & 10.6 & 10.2 & 10.5 & 10.6 & - \\
\hline \multirow[t]{2}{*}{$\mathrm{Fe}^{\mathrm{a}}$} & Bulk & 6.9 & 7.8 & 7.4 & 7.5 & 7.3 & 7.4 & 6.5 \\
\hline & Glass & 8.2 & 8.1 & 8.2 & 7.9 & 8.2 & 8.2 & \\
\hline \multirow[t]{2}{*}{$\mathrm{P}_{2} \mathrm{O}_{5}$} & Bulk & 0.7 & 0.7 & 0.7 & 0.6 & 0.8 & 0.8 & 0.5 \\
\hline & Glass & 0.9 & 0.9 & 0.8 & 0.8 & 0.8 & 0.7 & - \\
\hline \multirow[t]{2}{*}{$\mathrm{P}^{\mathrm{a}}$} & Bulk & 0.15 & 0.14 & 0.16 & 0.14 & 0.17 & 0.17 & 0.10 \\
\hline & Glass & 0.30 & 0.29 & 0.27 & 0.27 & 0.26 & 0.24 & \\
\hline \multirow{2}{*}{$\mathrm{MnO}$} & Bulk & 0.2 & 0.2 & 0.2 & 0.2 & 0.2 & 0.2 & 0.1 \\
\hline & Glass & 0.2 & 0.2 & 0.2 & 0.2 & 0.2 & 0.2 & - \\
\hline \multirow[t]{2}{*}{$\mathrm{MgO}$} & Bulk & 4.4 & 5.3 & 4.3 & 4.7 & 4.5 & 4.1 & 7.4 \\
\hline & Glass & 3.1 & 3.0 & 3.3 & 3.1 & 3.2 & 3.6 & - \\
\hline \multirow[t]{2}{*}{$\mathrm{CaO}$} & Bulk & 9.1 & 10.2 & 9.2 & 9.6 & 9.3 & 9.0 & 25.1 \\
\hline & Glass & 7.6 & 7.2 & 7.1 & 6.8 & 7.4 & 8.6 & - \\
\hline \multirow{2}{*}{$\mathrm{Na}_{2} \mathrm{O}$} & Bulk & 3.9 & 3.3 & 3.4 & 3.5 & 3.9 & 4.0 & 1.3 \\
\hline & Glass & 5.2 & 5.2 & 4.6 & 5.3 & 4.8 & 4.7 & - \\
\hline \multirow[t]{2}{*}{$\mathrm{K}_{2} \mathrm{O}$} & Bulk & 2.0 & 1.9 & 3.0 & 2.2 & 2.3 & 2.3 & 0.5 \\
\hline & Glass & 3.5 & 3.8 & 3.4 & 4.4 & 3.6 & 2.9 & - \\
\hline \multirow[t]{2}{*}{$\mathrm{TiO}_{2}$} & Bulk & 1.5 & 1.7 & 1.7 & 1.7 & 1.6 & 1.7 & 2.4 \\
\hline & Glass & 2.0 & 2.0 & 2.0 & 2.0 & 2.1 & 2.1 & - \\
\hline \multicolumn{9}{|c|}{ Trace elements (ppm) } \\
\hline $\mathrm{Zn}$ & Bulk & 101 & 99 & 94 & 104 & 108 & 110 & 87 \\
\hline $\mathrm{Cu}$ & Bulk & 112 & 155 & 164 & 136 & 158 & 150 & 45 \\
\hline
\end{tabular}

\footnotetext{
a Re-calculated from oxide-forms.
} 
release of $\mathrm{Zn}$ and $\mathrm{Cu}$ from the loess sample was below the detection limit $(<0.01 \mathrm{nmol} / \mathrm{g}$ ash $)$.

Based on the major and trace element contents, Cape Verde loess sample consists of $0.1 \mathrm{wt} . \%$ phosphorus (re-calculated from $\mathrm{P}_{2} \mathrm{O}_{5}$ ), 22 wt.\% $\mathrm{SiO}_{2}, 6.5$ wt.\% Fe (recalculated from $\mathrm{Fe}_{2} \mathrm{O}_{3}$ ), $87 \mathrm{ppm} \mathrm{Zn}$, and $45 \mathrm{ppm} \mathrm{Cu}$ (Table 3). The phosphorus content of Cape Verde loess sample is consistent with the Saharan soils from southern Algeria (Mills et al., 2004; Ridame and Guieu, 2002). Fe-content of the loess sample (6.5 wt.\%) was similar to those found for other Cape Verdean loess samples (7.6\% Fe; (Desboeufs et al., 2001)).

Nutrient-mobilization from the Cape Verde loess sample is within the range found for Etna ash (Table 2, Fig. 2). However, as we used only one type of dust sample, it is difficult then to assess the natural variability in the dust samples, thus making comparison with the wide range of observed values for the nutrient-release from Etna ash complicated. In terms of methodology, our study shows the first data for macro-nutrient release from dust in seawater, and therefore, provides a basis for comparison with volcanic ash. Comparison of total $\mathrm{P}$, $\mathrm{Si}$, Fe and $\mathrm{Zn}$ content of the bulk samples showed no correlation the release of P, Si, Fe and Zn (Fig. 2).

\section{Discussion}

The results of the geochemical experiments show that, upon a short contact time with seawater volcanic ash from Etna volcano readily dissolves macro-nutrients and trace metals that can be bioavailable for the phytoplankton in the nutrient-starved MedSea. The phytoplankton response to episodic volcanic ash inputs may see an initial response in a couple of days which can last up to several weeks (e.g., bloom related to Kasatochi eruption lasted 5-6 weeks (Hamme et al., 2010; Langmann et al., 2010)). Therefore, in order to evaluate the biogeochemical impacts of Etna ash, the ash-fall during single eruptions has to be considered. External supply of nutrients from volcanic ash fall during an explosive Etna eruption can be constrained by combining the amount of ash deposition $\left(\mathrm{g} / \mathrm{m}^{2}\right)$ and the nutrient release per gram of Etna ash (nmol/g ash).

\subsection{Volcanic ash-fall during an explosive eruption of Mount Etna}

Although a large fraction of ash ejected from most of the explosive Etna eruptions has been deposited offshore, the amount of ash fall in the MedSea has not been constrained yet. Marine ash layers are generally used for correlating and mapping of the ash deposition areas in the ocean (isomass maps) (Kutterolf et al., 2008). Such drill core studies are, however, very rare world-wide, except for the Central American volcanic arc (Kutterolf et al., 2008) and for the 1991 Pinatubo volcanic eruption in the Philippines (Wiesner et al., 1995). In the absence of correlated Etna ashes in marine sediments, an alternative way to estimate the ash deposition in the open sea is to combine the onshore data with the ash fall records in remote distances (e.g., Greece). We estimated the amount of ash fall in $\mathrm{g} / \mathrm{m}^{2}$ as a function of distance downwind in the MedSea by using the 4-5 November 2002 activity as a case study, by using the universal relation between the thickness of the ash layers and the depositional areas (Fierstein and Nathenson, 1992; Pyle, 1989).

Intense explosive activity that started on 4 November 2002 lasted about $18 \mathrm{~h}$, generating ash plumes reaching up to $\sim 6 \mathrm{~km}$ above the sea level (a.s.l.) and ejecting about $1.4 \times 10^{12} \mathrm{~g}$ of tephra (Andronico et al., 2005). Ash-fall in the coastal region during 4 November 2002 eruption ranged from $300 \mathrm{~g} / \mathrm{m}^{2}$ to $2000 \mathrm{~g} / \mathrm{m}^{2}$, which was extrapolated by using the ash layers collected on land (Andronico et al., 2008b). Volcanic ash ejected from this event was transported as far as Greece, depositing $0.3 \mathrm{~g} / \mathrm{m}^{2}$ of ash in Athens (20 mg of ash collected over sampled over $706 \mathrm{~cm}^{2}$ collectors) (Kelepertsis et al., 2003). Based on the backward wind trajectories (Kelepertsis et al., 2003), the eruption plume traveled around $800 \mathrm{~km}$ from the volcano (see Supplementary material). In order to estimate the amount of ash-fall between Mount Etna and
Athens, we used the relation between the thickness and the area of ash deposits. Since fallout deposits thin exponentially from the source, the relation between the $\ln$ [thickness] and the square root [area] is quasi-linear (Fierstein and Nathenson, 1992; Pyle, 1989). Based on the In [thickness] versus sqrt [area] graphs, it is possible to calculate the ash-layer thicknesses for given isopach areas. The method used for ash deposition estimates is provided in detail in the Supplementary material. Only for the 4 November 2002 eruption it was possible to use this method, as the ash deposition in other places (e.g., Libya or Kefalonia) was not measured.

Based on our ash fall estimates, the amount of ash deposition gradually decreases downwind from the volcano (Table 4). The maximum variation (based on the range of ash density) is about $\pm 1.5 \mathrm{~g} / \mathrm{m}^{2}$ ranging from $231 \mathrm{~g} / \mathrm{m}^{2}$ to $234 \mathrm{~g} / \mathrm{m}^{2}$ found at $100 \mathrm{~km}$ distance from the volcanic source. The variation in the ash-load decreases down to less than $0.1 \mathrm{~g} / \mathrm{m}^{2}$ ash in $800 \mathrm{~km}$ downwind from the volcanic source (Table 4). Ash deposition estimations involve some uncertainties related to dimensions of isomasses (discussed in Supplementary material), however, the variations in the open sea can be considered as negligible in terms of nutrient supply since the nutrient solubility of Etna ash samples is highly variable (Table 2 ). These ash fall estimations are representative for moderate level eruptions similar to 4 November 2002 event, notably, higher-level eruptions can deposit 10 to 100 times more ash into the sea (e.g., 1991 Pinatubo 1991 eruption deposited $>20 \mathrm{~g} / \mathrm{m}^{2}$ ash in the South China Sea as far $600 \mathrm{~km}$ from the volcano (Wiesner et al., 1995)).

By using the ash deposition estimates based on 4 November 2002 event, it is possible to compare the ash flux with the dust deposition during dust storm events in the MedSea. Low frequent extreme dust events deposit about $29 \mathrm{~g} / \mathrm{m}^{2}$ (measured at DYFAMED side in the western MedSea) (Ternon et al., 2010). Average dust storms deposit about $10 \mathrm{~g} / \mathrm{m}^{2}$ dust (Guieu et al., 2010); while relatively more frequent low-level dust events deposit around $0.05 \mathrm{~g} / \mathrm{m}^{2}$ dust (Ternon et al., 2010). Estimated volcanic ash flux during the 4 November 2002 event 10-50 times exceeds the extreme dust events 300-350 km downwind from the eruption source (Table 4 ), the amount of the ash fall is above an average dust storm event $400-450 \mathrm{~km}$ downwind from the volcano, and the amount of ash fall is above the frequent low-level dust events of $0.05 \mathrm{~g} / \mathrm{m}^{2}$ dust flux as far as $800 \mathrm{~km}$ from the volcanic source (Table 4).

\section{Table 4}

Amount of volcanic ash deposition as a function of distance from Mount Etna, based on 4 November 2002 ash emission used as a case study. Estimations in this study were based on the linear relation between the natural logarithm of ash layer thicknesses and the square root of the depositional areas (Fierstein and Nathenson, 1992; Pyle, 1989). Ash densities used in the estimations are $2100 \mathrm{~kg} / \mathrm{m}^{3}$ and $3100 \mathrm{~kg} / \mathrm{m}^{3}$, representative for Etna ash (D. Andronico, unpublished data). Thickness conversions are done by using 30\% porosity for proximal and distal ash layers, and 50\% and 30\% interparticle pore spaces for proximal and distal of the ash deposits, respectively (Kutterolf et al., 2008). The method for ash deposition estimations is provided in detail in the Supplementary material.

\begin{tabular}{|c|c|c|c|}
\hline $\begin{array}{l}\text { Distance downwind } \\
\text { from Etna }\end{array}$ & $\begin{array}{l}\text { Isomass } \\
\text { width }\end{array}$ & $\begin{array}{l}\text { Amount of volcanic } \\
\text { ash deposition }\end{array}$ & Data source \\
\hline $11 \mathrm{~km}$ (onshore) & $5 \mathrm{~km}$ & $5000 \mathrm{~g} / \mathrm{m}^{2}$ & Andronico et al. (2008b) \\
\hline $17 \mathrm{~km}$ (onshore) & $9 \mathrm{~km}$ & $3000 \mathrm{~g} / \mathrm{m}^{2}$ & Andronico et al. (2008b) \\
\hline $21 \mathrm{~km}$ (Ionian coast) & $12 \mathrm{~km}$ & $2000 \mathrm{~g} / \mathrm{m}^{2}$ & Andronico et al. (2008b) \\
\hline $31 \mathrm{~km}$ & $15 \mathrm{~km}$ & $1000 \mathrm{~g} / \mathrm{m}^{2}$ & Andronico et al. (2008b) \\
\hline $55 \mathrm{~km}$ & $20 \mathrm{~km}$ & $300 \mathrm{~g} / \mathrm{m}^{2}$ & Andronico et al. (2008b) \\
\hline $100 \mathrm{~km}$ & $30 \mathrm{~km}$ & $231-233 \mathrm{~g} / \mathrm{m}^{2}$ & This study \\
\hline $200 \mathrm{~km}$ & $52 \mathrm{~km}$ & $90-94 \mathrm{~g} / \mathrm{m}^{2}$ & This study \\
\hline 300 km & $74 \mathrm{~km}$ & $36-38 \mathrm{~g} / \mathrm{m}^{2}$ & This study \\
\hline $400 \mathrm{~km}$ & $97 \mathrm{~km}$ & $14-15 \mathrm{~g} / \mathrm{m}^{2}$ & This study \\
\hline $500 \mathrm{~km}$ & 119 km & $5.6-6.3 \mathrm{~g} / \mathrm{m}^{2}$ & This study \\
\hline $600 \mathrm{~km}$ & 141 km & $2.2-2.6 \mathrm{~g} / \mathrm{m}^{2}$ & This study \\
\hline $700 \mathrm{~km}$ & 164 km & $0.9-1.0 \mathrm{~g} / \mathrm{m}^{2}$ & This study \\
\hline $800 \mathrm{~km}$ & 189 km & $\begin{array}{l}0.3 \mathrm{~g} / \mathrm{m}^{2} \text { (Athens } \\
\text { ash fall) }\end{array}$ & Kelepertsis et al. (2003) \\
\hline
\end{tabular}


4.2. Biogeochemical implications of nutrient supply during an Etna eruption

The region that is frequently affected by the Etna ash fallout is the central MedSea including mostly the Ionian Sea and the Tyrrhenian Sea (Fig. 1). The phytoplankton biomass in the Ionian basin has been characterized by annual maxima in late winter and annual minima in late summer, with a decreasing trend from north to south in terms of magnitude of response (D'Ortenzio and D'Alcala, 2009). The ultimate limiting nutrient for the phytoplankton growth in the MedSea has long been considered to be P (Bonnet et al., 2005; Guerzoni et al., 1999; Thingstad and Rassoulzadegan, 1995; Thingstad et al., 1998), with an increasing trend from west to east (Krom et al., 1991), while recent studies suggested limitation of nitrogen $(\mathrm{N})$ in the western and central MedSea and co-limitation of $\mathrm{N}$ and $\mathrm{P}$ in the eastern basin (Tanaka et al., 2011). Depending on the time of the year the region limitation may shift to another macro-nutrient such as silica ( $\mathrm{Si}$ ) associated particularly to diatom production (Leblanc et al., 2005). Fertilizing potential of Etna ash fallout has been evidenced by the two to three times increased chlorophyll-a concentrations which were correlated with increased Fe-concentrations in the ash fallout region in the Ionian Sea during July 2001 eruption (Censi et al., 2010). However, due to lack of macronutrient measurements ( $\mathrm{N}$ and $\mathrm{P}$, especially) in the Etna ash fall region in the Ionian Sea, the main mechanisms resulted to the chlorophyll-a increase remained largely unknown.

Here we predicted the input of dissolved nutrients in the surface water (upper $1 \mathrm{~m}$ ) by using ash fall estimates based on 4 November 2002 case and the nutrient-release from Etna ash and Cape Verde loess. Relatively longer residence times of particles in the atmosphere-sea interface (e.g., upper $40 \mathrm{~cm}$ ) may result to a transient decrease in nutrient release over water depth (Pulido-Villena et al., 2010). We assumed a homogenous distribution of particles within the $1 \mathrm{~m}$ of the water column, which may underestimate the possible nutrient enrichment in the sea surface. In addition, nutrient release from ash particles is probably not linearly correlated with ash particle concentrations (Baker and Jickells, 2006). It is therefore very likely that, the nutrient-supply of nutrients estimated below may underestimate actual supply in the open sea (with low ash-fluxes) and may overestimate the supply in the coastal regions with extremely high particle fluxes. Furthermore, a fraction of the nutrients in the seawater may be scavenged by adsorption onto the ash particle surface, similar to what has been suggested for dust particles (Ridame et al., 2003).

\subsubsection{Phosphate}

P-concentrations in the MedSea are as low as $<1-6 \mathrm{nM}$ throughout the stratified period between May and December (Fig. 4) (Krom et al., 2005; Pulido-Villena et al., 2010). The highest P-concentrations are found during winter mixed period reaching values of 200-350 nM, which decrease down to $30 \mathrm{nM}$ after the spring bloom in April (Pulido-Villena et al., 2010). The highest possible input of P estimated based on the maximum P-release from Etna ash would range from $226 \mathrm{nM}$ up to $1940 \mathrm{nM}$ within the ash fallout region in the first $100 \mathrm{~km}$ downwind from the volcano, which is above the highest P-concentrations during winter mixed period (Fig. 4). The lowest estimate for P-input (based on minimum P-release) would range from $2 \mathrm{nM}$ to $14 \mathrm{nM}$, which can provide an important source of P throughout the stratified period (Fig. 4). Based on the P-release per $g$ of Cape Verdean loess in our study (43 nmol/g, Table 2), P-input by during dust events is below $1.2 \mathrm{nM}$. Based on P-uptake measurements, the concentration of bioavailable $P$ was estimated to be $3 \mathrm{nM}$ (Moutin et al., 2002). Assuming $3 \mathrm{nM}$ of $\mathrm{P}$ a threshold for biological response, P-fertilization potential of Etna ash fallout can extend as far as $600 \mathrm{~km}$ in the MedSea, with the highest impact within the first $100-150 \mathrm{~km}$ downwind from the volcano (Fig. 4). Therefore, following the deposition of volcanic ash into the sea surface, ash plumes ejected from Etna may have significant effect on the MPP through supplying P, the ultimate limiting nutrient in the surface MedSea.

\subsubsection{Nitrogen}

$\mathrm{N}$-concentrations during the stratified season in the MedSea are as low as P (less than detection limits of $50 \mathrm{nM}$ ) (Bonnet et al., 2005; Mihalopoulos et al., 1997). Since the nutrient limitation in the MedsEa may immediately shift $\mathrm{P}$ to $\mathrm{N}$ or vice versa (Herut et al., 2005), addition of an array of nutrients may enhance MPP more effectively compared to the addition of a single element. The concentrations of fixed-N to maintain phytoplankton demand in some coastal regions in the MedSea found to be high (e.g., $220 \mathrm{nM}$ in the coastal zone of Gulf of Lion) (Diaz and Raimbault, 2000), while the requirement of fixed-N is probably lower in the open sea. The input of total fixed-N related to Etna ash fallout would be $70-1710 \mathrm{nM}$ in the coast, $8-200 \mathrm{nM}$ in the first $100 \mathrm{~km}$ downwind from the volcano, decreasing $0.5-13 \mathrm{nM}$ at distances $400 \mathrm{~km}$ (Fig. 4). The maximum input of fixed-N from Etna ash would be above $250 \mathrm{nM}$ up to about $50 \mathrm{~km}$ downwind from the volcano, which can be considered as significant for MPP, while the minimum estimates are slightly lower than the limit to sustain $\mathrm{N}$ demand for new production (e.g., 61-123 nM, in the $30 \mathrm{~km}$ coastal zone) (Fig. 4).

Based on N-release from our Cape Verde dust sample, dust deposition in the upper $1 \mathrm{~m}$ of the water column would be 16-18 nM during extreme dust storms $\left(29 \mathrm{~g} / \mathrm{m}^{2}\right), 5-6 \mathrm{nM}$ during average dust storms $\left(10 \mathrm{~g} / \mathrm{m}^{2}\right)$ and $<0.03 \mathrm{nM}$ during low intensity dust events $\left(0.05 \mathrm{~g} / \mathrm{m}^{2}\right)$. $\mathrm{N}$-supply from dust deposition suggests that dust storms can provide significant $\mathrm{N}$ during dust storms, while the impact of low level dust deposition can be considered as negligible in terms of biological response.

\subsubsection{Iron}

Despite the high input of Fe-bearing desert dust in the MedSea, Fe-concentrations are very low $<0.13 \mathrm{nM}$ in the open sea (Sarthou and Jeandel, 2001) and $<1-3 \mathrm{nM}$ in the coastal region in the Ionian Sea (Censi et al., 2010). It has been suggested that the deposition of reduced Fe to surface waters of MedSea has the potential to induce phytoplankton blooms (Saydam, 1996). For example, Fe-concentrations during a Saharan dust storm on July 1988 (off the coast of Libya) were increased by $6 \mathrm{nM}$, which has been suggested to create an Emiliania huxleyi bloom that has been evidenced by the Meteosat scenes (Dulac et al., 1996). In contrast, a recent mesocosm study in the western MedSea suggested that, through scavenging of Fe on to the dust particles (by $0.4 \pm 0.1 \mathrm{nmol} \mathrm{Fe} / \mathrm{mg}$ dust), high particle fluxes during large-scale dust events might act as sink of Fe rather than a source (Wagener et al., 2010). Fe-input for Cape Verde loess is relatively low compared to volcanic ash, which ranges $0.6-0.9 \mathrm{nM}, 0.2-0.3 \mathrm{nM}$, and $<0.01 \mathrm{nM} \mathrm{Fe}$ for the extreme dust events, average dust storms and low level dust events, respectively.

Microcosm experiments with seawater collected from MedSea showed that addition of Fe + P more effectively stimulates MPP compared to the addition of Fe alone or $\mathrm{P}$ alone, which has been linked to increased $\mathrm{N}_{2}$-fixation that is co-limited by P and Fe (Bonnet et al., 2005). Since Etna ash provides $\mathrm{P}$ along with $\mathrm{Fe}$, ash fallout from Etna can therefore impact the surface $\mathrm{N}$-concentrations directly through nutrient dissolution and/or indirectly through $\mathrm{N}_{2}$-fixation by the addition of $\mathrm{P}$ and Fe. The contribution of $\mathrm{N}_{2}$-fixation can reach up to $35 \%$ of new production in the western basin, while the impact is found to be negligible in the eastern Levantine Basin (Bonnet et al., 2011). Due to the decreasing impact of $\mathrm{N}_{2}$-fixation from west to east, Etna ash plumes that are transported to western direction (e.g., Tyrrhenian Sea) would have more impact on the $\mathrm{N}_{2}$-fixation compared to the plumes transported to the east towards the Ionian Sea.

Dry deposition of Etna ash can supply $22-260 \mathrm{nM}$ of Fe in the coast, and 10-130 nM of Fe about $30 \mathrm{~km}$ from the coast, $1-12 \mathrm{nM}$ within $300 \mathrm{~km}$ distance, decreasing down to $0.1 \mathrm{nM}$ to $2 \mathrm{nM}$ in the distances $400 \mathrm{~km}$ downwind from the volcano (Fig. 4). Dissolved Fe concentrations in the Ionian coast within the Etna ash fallout region 
Total fixed-N (nM)

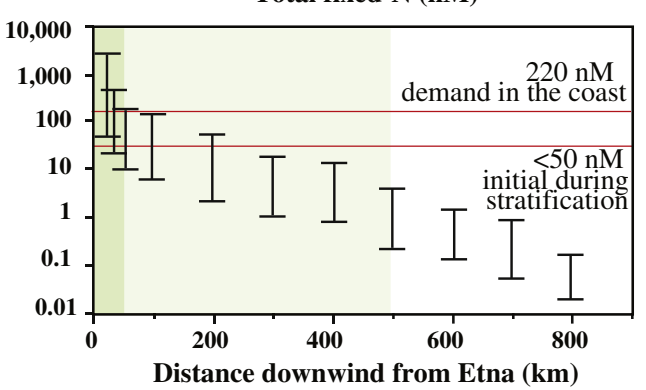

$\mathrm{Si}(\mathrm{nM})$

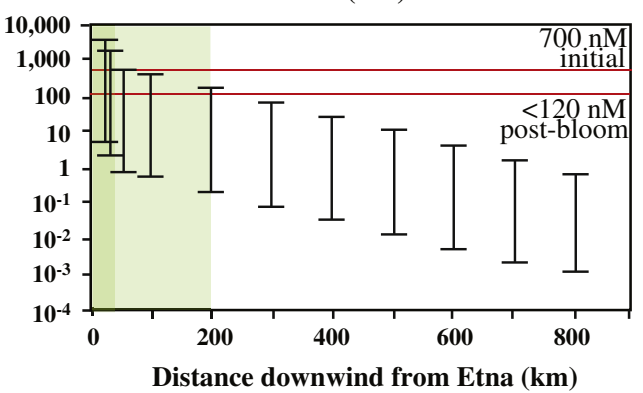

Zn (nM)

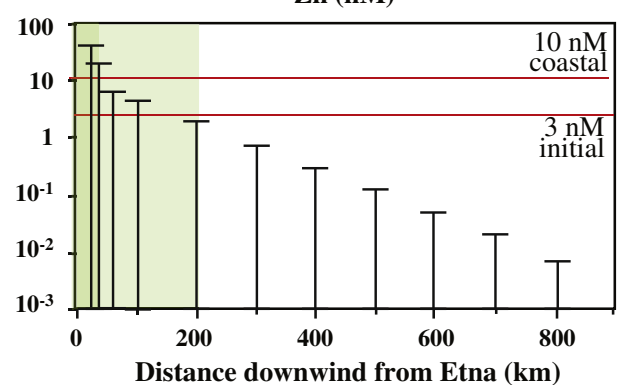

$\mathbf{P}(\mathbf{n M})$

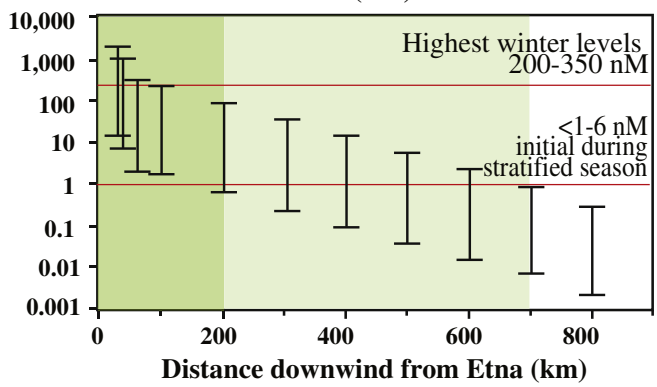

$\mathrm{Fe}(\mathrm{nM})$

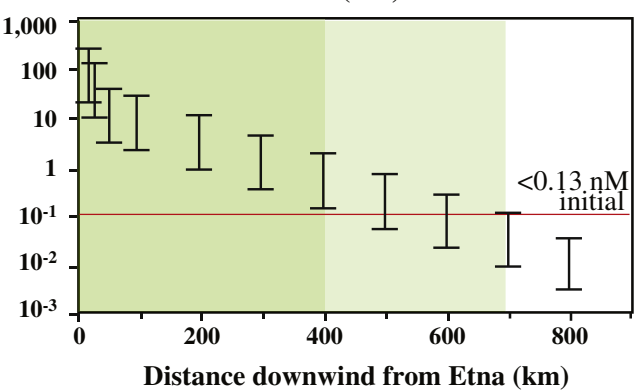

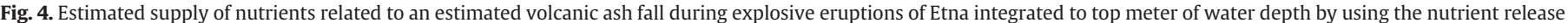

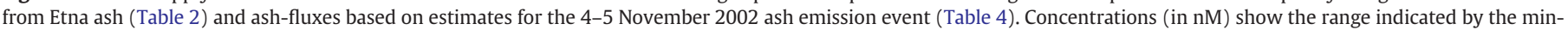

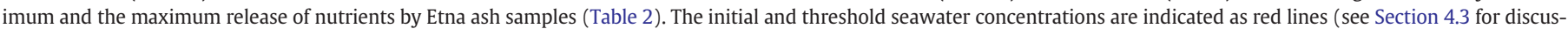

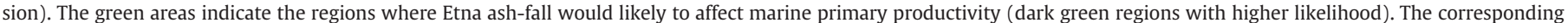
distances downwind from Etna are shown in the MedSea map in Fig. 3.

during 21 July 2001 were by 600-670 nM (Censi et al., 2010), significantly higher compared to our estimates based on the new geochemical data (highest by $260 \mathrm{nM}$ ) (Fig. 4). High concentrations of dissolved Fe in the ash fallout region can be due to the increased lysis of phytoplankton (by grazing), which may in turn increase the complexation of the Fe released from Etna ash (i.e. higher organic ligand concentrations) (Censi et al., 2010). Also, through storage time of our samples, a possible decay of the soluble Fe-compounds (e.g., Fe-bearing salts) may have resulted to a reduction in the actual Fe-mobilization from volcanic ash (Jones and Gislason, 2008; Olgun et al., 2011).

\subsubsection{Silica}

Si-concentrations in the MedSea are relatively high during the stratified season (700 nM) (Fig. 4) (Bonnet et al., 2005; Schink and Kingston, 1967). However, severe Si-limitation of diatom spring blooms has been observed at least for one coastal zone, in the Gulf of Lion, where the Si concentrations were lowered down to $120 \mathrm{nM}$, indicating the significance of Si especially after the spring bloom period (Leblanc et al., 2005), which is an ultimate nutrient required by the diatoms, dominating the new production in the MedSea (Socal et al., 1999). Furthermore, recent biological experiments have shown that, when grown in ash-fertilized seawater, diatoms (e.g., Thalassiosira pseudonana) benefit more from volcanic ash compared to coccolithopores (e.g., Emiliania huxleyi) (Hoffmann et al., 2012). It is therefore very likely that ash fallout from Etna may change the composition of phytoplankton assemblage towards domination of diatoms in the surface water, and further increase demand of $\mathrm{Si}$ in the euphotic zone. The maximum Si-input from Etna ash fallout within $200 \mathrm{~km}$ downwind from volcano would range 193-4115 $\mu \mathrm{M}$, suggesting that Etna eruptions can impact on Si-budget in the surface of MedSea waters (Fig. 4). However, the minimum supply of Si is probably insignificant (below $5 \mathrm{nM}$ ) pointing out the importance of the Si-mobilization behavior of the ash (Fig. 4). Si-supply based on the data from Cape Verde loess sample would range between 13-32 nM, 5-11 nM, and $<0.1 \mathrm{nM}$ calculated for the extreme dust events, average dust storms and low level dust events, respectively.

\subsubsection{Zinc}

Typical Zn-levels are around $3 \mathrm{nM}$ in the MedSea (Ruiz-Pino et al., 1991), with highest $\mathrm{Zn}$ concentrations of $10 \mathrm{nM}$ found in the Alboran Sea (Sherrell and Boyle, 1988). Zinc is a bioactive trace metal required by the phytoplankton and also a co-factor in alkaline phosphatase enzyme that allows phytoplankton to utilize phosphate from organic compounds (Morel and Price, 2003). In the North Atlantic Ocean, 
Table 5

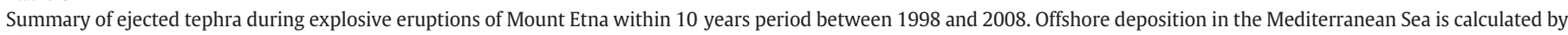
assuming $50 \%$ of ejected tephra deposited offshore.

\begin{tabular}{|c|c|c|c|}
\hline Year & Period & Description & Deposited tephra mass \\
\hline 1998 & 11 June 1998-4 Feb. 1999 & $\begin{array}{l}>22 \text { paroxysms, alternating magnitude of eruptions on the Voragine } \\
\text { Crater. Plumes reached } 12 \mathrm{~km} \text { (a.s.l.) on } 22 \text { July } 1998 .\end{array}$ & $\begin{array}{l}0.8-3.0 \times 10^{12} \mathrm{~g}^{(\mathrm{a}, \mathrm{b})} \text { on } 22 \text { July } 1998 \\
\text { (in } 12 \mathrm{~min})\end{array}$ \\
\hline 2000 & $\begin{array}{l}26 \text { Jan.-24 June } \\
28-29 \text { Aug. }\end{array}$ & $\begin{array}{l}\text { Paroxysm events reached up to } 3 \text { times per day on some days in } \\
\text { February, } 64 \text { lava fountain episodes within less than six months. } \\
\text { Plumes reached a maximum height of } 6 \mathrm{~km} \text { a.s.l. }\end{array}$ & $6.3-9.6 \times 10^{9} \mathrm{~g}^{(\mathrm{c}) \mathrm{a}}$ \\
\hline 2001 & 17 July-9 Aug. & $\begin{array}{l}\text { Flank eruptions in the SE crater. The most explosive phases } 20-24 \text { July } \\
\text { and } 31 \text { July- } 5 \text { August. Plumes reached } 5 \mathrm{~km} \text { a.s.l. Closure of Catania } \\
\text { airport for several days. }\end{array}$ & $\begin{array}{l}18 \times 10^{12} \mathrm{~g}^{(\mathrm{d})} \\
1.0-2.3 \times 10^{12} \mathrm{~g}^{(\mathrm{e})}\end{array}$ \\
\hline $2002-2003$ & 27 Oct. 2002-9 Jan. 2003 & $\begin{array}{l}\text { Phreatomagmatic intense activity in the SE crater. Plumes rose } \\
4-6 \mathrm{~km} \text { high a.s.l., reached Greece and Libya (Dellino and } \\
\text { Kyriakopoulos, 2003; Kelepertsis et al., 2003). The plume tracked } \\
\text { over } 1000 \mathrm{~km} \text { into the North Africa. }\end{array}$ & $\begin{array}{l}38-50 \times 10^{12} \mathrm{~g}^{(\mathrm{f}, \mathrm{g}, \mathrm{h})} \\
\text { (the entire period) }\end{array}$ \\
\hline 2006 & 14-31 July and 31 Aug.-15 Dec. & $\begin{array}{l}\text { Alternating eruptive intensity with light to moderate ash fallout } \\
\text { lasting several hours to } 2-4 \text { days intervals. }\end{array}$ & $\begin{array}{l}>0.4 \times 10^{12} \mathrm{~g}^{(\mathrm{i}, \mathrm{j}, \mathrm{k})} \\
\text { (total of some daily records) }\end{array}$ \\
\hline 2007 & $\begin{array}{l}\text { 11-29 Apr., } 15-21 \text { Aug. } 4-5 \text { Sept., } \\
1 \text { Oct-24 Nov. }\end{array}$ & $\begin{array}{l}\text { Long-lasting powerful lava fountain episodes started at the SE crater. } \\
\text { Plumes reached } 5 \mathrm{~km} \text { a.s.l. }\end{array}$ & $\begin{array}{l}3.1-4.5 \times 10^{6} g^{(1) a} \\
(4-5 \text { September })\end{array}$ \\
\hline \multicolumn{3}{|c|}{ Ejected tephra between 1998 and 2008} & $41-76 \times 10^{12} \mathrm{~g} /$ decade \\
\hline \multicolumn{3}{|c|}{ Offshore ash flux into the MedSea (assuming 50\% of the ejected material is deposited offshore) ${ }^{(\mathrm{m})}$} & $\begin{array}{l}20-27 \times 10^{12} \mathrm{~g} / \text { decade } \\
\left(2-3 \times 10^{12} \mathrm{~g} / \text { year }\right)\end{array}$ \\
\hline
\end{tabular}

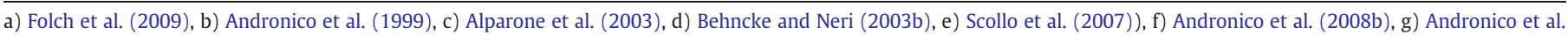
(2005), h) Carn (2005), i) Andronico et al. (2009a), j) Andronico et al. (2009b), k) Corradini et al. (2008), l) Andronico et al. (2008a), m) Olgun et al. (2011).

a Tephra volumes are converted to mass by using two densities $2100 \mathrm{~kg} / \mathrm{m}^{3}$ and $3100 \mathrm{~kg} / \mathrm{m}^{3}$ representative for Etna ash.

the lessening of P-limitation of $\mathrm{N}$-fixers was linked to $\mathrm{Zn}$ that is possibly introduced by the dust particles (Mills et al., 2004). However, some of the ash samples and also the Cape Verde loess sample did not show any Zn-release during the first hour contact with seawater (Fig. 4). Highest input of $\mathrm{Zn}$ related to the Etna ash fallout would be $42 \mathrm{nM}$ in the coast, and above $3 \mathrm{nM}$ in distances about $150 \mathrm{~km}$ downwind from Etna (Fig. 4). Addition of Zn together with P by the ash fall may therefore increase the up-take of $\mathrm{P}$ and relieve the P-limitation in the MedSea.

\subsubsection{Copper}

The MedSea, especially the central and eastern part, is close to Cu-toxicity during large part of the year (Paytan et al., 2009). Our voltammetric experiments showed that, Etna ash releases no detectable amounts of $\mathrm{Cu}$ during the first hour of interaction with seawater. This is consistent with the long-term kinetic experiments by Etna ash showing that the dissolved Cu concentrations remain below $1 \mathrm{nM}$ until the end of the first week (Censi et al., 2010). Therefore, our study suggests that the volcanic ash fallout during Etna eruptions is unlikely to increase the Cu-toxicity in the MedSea.

\subsection{Input of Etna volcanic ash and mineral dust in the MedSea}

The MedSea is one of the highest dust input regions in the global ocean $\left(20-50 \times 10^{12} \mathrm{~g} / \mathrm{y}\right)$, with dust input of $3-7 \times 10^{12} \mathrm{~g} / \mathrm{y}$ in the western, $4-11 \times 10^{12} \mathrm{~g} / \mathrm{y}$ in the central, and $13-32 \times 10^{12} \mathrm{~g} / \mathrm{y}$ in the eastern MedSea (Guerzoni et al., 1999). The total amount of tephra ejected from Etna during a ten year period between 1998 and 2008 is about $40-53 \times 10^{12} \mathrm{~g}$ (Table 5). However, the ash fraction that has been deposited in the MedSea is unknown, which is very dependent on the eruption column height, wind direction and grain size distribution of the ash plume. Based on the ash layers found in the eastern equatorial Pacific Ocean marine drill cores, the fraction of ash that is deposited offshore is found to be $80 \pm 10 \%$ of the ejected tephra from the Central American volcanoes (Kutterolf et al., 2008; Olgun et al., 2011). Assuming that at least half of the ejected tephra from Etna was deposited into the MedSea (which can be considered as minimum), the amount of offshore ash input corresponds to $2-3 \times 10^{12} \mathrm{~g} / \mathrm{y}$ (Table 5), which is about $25-50 \%$ of the annual dust deposition in the central MedSea $\left(4-11 \times 10^{12} \mathrm{~g} / \mathrm{y}\right)$. It is important to note that a single eruption of Etna can deposit ash in the sea in amounts comparable to the yearly dust input in the central MedSea (as high as $1.5 \times 10^{12} \mathrm{~g}$ on 22 July
1998, assuming 50\% offshore; Table 5). The ash layers in the seafloor probably contribute about one fourth of the marine sediments in the central MedSea floor, which may also provide additional nutrients through upwelling during mixed winter conditions. Compared to the more widespread inputs of desert dust that affect the entire MedSea, the impact of Etna ash affects mainly the central MedSea region.

Over the last decades, due to a gradual transition of the magma source (Branca and Del Carlo, 2005; Schiano et al., 2001), there has been a dramatic increase in the frequency of explosive eruptions of Etna (Andronico et al., 2005; Behncke and Neri, 2003a; Branca and Del Carlo, 2005). Between 1995 and 2011 Mount Etna produced more than 150 eruptive episodes (Andronico et al., 2008b). Focusing exclusively on the ash producing events, the explosive eruptions of Etna can be considered as episodic. However, frequent episodes can occur within a single day and notably explosivity can last several months like the 2002-2003 eruptive activity (Table 5). Increased explosivity of the Etna over the last decades, suggests that the biogeochemical impact of Etna ash fallout on the MPP in the nutrient-starved LNLC MedSea is likely to increase in the near future.

\section{Conclusions}

Volcanic ash ejected during Etna eruptions releases fixed-N, P, Si, Fe and Zn into seawater. Ash-fall estimates based on the 4-5 November 2002 Etna ash emission event showed that, during explosive eruptions Etna volcanic ash-fall in the central MedSea exceeds the particle flux during extreme dust storm events. New supply of nutrients during explosive eruptions of Etna can provide an atmospheric source of nutrients in the oligotrophic surface waters of MedSea, Etna ash fallout may provide a good source of dissolved nutrients and can eventually impact the MPP in the central MedSea.

\section{Acknowledgments}

This study was supported by Helmholtz-Center for Ocean Research, GEOMAR through the multidisciplinary research group NOVUM "Nutrients originating volcanoes and their effects on the euphotic zone of the marine ecosystem" and contribution number 174 of the Sonderforschungsbereich (SFB) 574 "Volatiles and Hazards in Subduction Zones". We are grateful to Antonio Cristaldi and Simona Scollo; INGV-Sezione di Catania for their help in the 
ash sample collection, and Deborah Lo Castro (INGV-Sezione di Catania) for assisting in the sample selection. We thank Frank Malien for helping during the photometric measurements and M. Thoener for technical assistance with the electron microprobe analyses.

\section{Appendix A. Supplementary data}

Supplementary data to this article can be found online at http:// dx.doi.org/10.1016/j.marchem.2013.04.004.

\section{References}

Alparone, S., Andronico, D., Lodato, L., Sgroi, T., 2003. Relationship between tremor and volcanic activity during the Southeast Crater eruption on Mount Etna in early 2000. J. Geophys. Res. 108

Andronico, D., Del Carlo, P., Coltelli, M., 1999. The 22 July 1998 fire fountain episode at Voragine Crater (Mt. Etna, Italy). Proceedings of the Volcanic and Magmatic Studies Group - Annual Meeting, Birmingham.

Andronico, D., et al., 2005. A multi-disciplinary study of the 2002-03 Etna eruption: insights for a complex plumbing system. Bull. Volcanol. 67, 314-330.

Andronico, D., Cristaldi, A., Scollo, S., 2008a. The 4-5 September 2007 lava fountain at South-East Crater of Mt Etna, Italy. J. Volcanol. Geotherm. Res. 173, 325-328.

Andronico, D., Scollo, S., Caruso, S., Cristaldi, A., 2008b. The 2002-03 Etna explosive activity: tephra dispersal and features of the deposits. J. Geophys. Res. 113.

Andronico, D., Scollo, S, Cristaldi, A., Ferrari, F, 2009a. Monitoring ash emission episodes at Mt. Etna: the 16 November 2006 case study. J. Volcanol. Geotherm. Res. $180,123-134$

Andronico, D., Spinetti, C., Cristaldi, A., Buongiorno, M.F., 2009b. Observations of Mt Etna volcanic ash plumes in 2006: an integrated approach from ground-based and polar satellite NOAA-AVHRR monitoring system. J. Volcanol. Geotherm. Res. $180,135-147$.

Baker, A.R., Jickells, T.D., 2006. Mineral particle size as a control on aerosol iron solubility. Geophys. Res. Lett. 33.

Behncke, B., Neri, M., 2003a. Cycles and trends in the recent eruptive behaviour of Mount Etna (Italy). Can. J. Earth Sci. 40, 1405-1411.

Behncke, B., Neri, M., 2003b. The July-August 2001 eruption of Mt. Etna (Sicily). Bull. Volcanol. 65, 461-476.

Bethoux, J.P., et al., 1998. Nutrients in the Mediterranean Sea, mass balance and statistical analysis of concentrations with respect to environmental change. Mar. Chem. 63, 155-169.

Bonnet, S., Guieu, C., 2004. Dissolution of atmospheric iron in seawater. Geophys. Res Lett. 31.

Bonnet, S., Guie, C., Chiaverini, J., Ras, J., Stock, A., 2005. Effect of atmospheric nutrients on the autotrophic communities in a low nutrient, low chlorophyll system. Limnol. Oceanogr. 50, 1810-1819.

Bonnet, S., Grosso, O., Moutin, T., 2011. Planktonic dinitrogen fixation along a longitudinal gradient across the Mediterranean Sea during the stratified period (BOUM cruise). Biogeosciences 8, 2257-2267.

Branca, S., Del Carlo, P., 2005. Types of eruptions of Etna volcano AD 1670-2003: implications for short-term eruptive behaviour. Bull. Volcanol. 67, 732-742.

Carn, S.A., 2005. Quantifying tropospheric volcanic emissions with AIRS: the 2002 eruption of Mt. Etna (Italy). Geophys. Res. Lett. 32.

Censi, P., et al., 2010. Trace element behaviour in seawater during Etna's pyroclastic ac tivity in 2001: concurrent effects of nutrients and formation of alteration minerals. J. Volcanol. Geotherm. Res. 193, 106-116.

Corradini, S., et al., 2008. Mt. Etna tropospheric ash retrieval and sensitivity analysis using Moderate Resolution Imaging Spectroradiometer measurements. J. Appl. Remote. Sens. 2

Croot, P., Johansson, M., 2000. Determination of iron speciation by cathodic stripping voltammetry in seawater using the competing ligand 2-(2-Thiazolylazo)-p-creaso (TAC). Electroanalysis 12 (8), 565-576.

D'Ortenzio, F., D'Alcala, M.R., 2009. On the trophic regimes of the Mediterranean Sea: a satellite analysis. Biogeosciences 6, 139-148.

Dellino, P., Kyriakopoulos, K., 2003. Phreatomagmatic ash from the ongoing eruption of Etna reaching the Greek island of Cefalonia. J. Volcanol. Geotherm. Res. 126, 341-345.

Desboeufs, K.V., Losno, R., Colin, J.L., 2001. Factors influencing aerosol solubility during cloud processes. Atmos. Environ. 35, 3529-3537.

Diaz, F., Raimbault, P., 2000. Nitrogen regeneration and DON release during $15 \mathrm{~N}$ experiments during spring in a north-western Mediterranean coastal zone (Gulf of Lions): implications on the estimations of $\mathrm{f}$ ratio and new production. Mar. Ecol. Prog. Ser. 197, 53-66.

Duggen, S., Croot, P., Schacht, U., Hoffmann, L., 2007. Subduction zone volcanic ash can fertilize the surface ocean and stimulate phytoplankton growth: evidence from biogeochemical experiments and satellite data. Geophys. Res. Lett. 34

Duggen, S., et al., 2010. The role of airborne volcanic ash for the surface ocean biogeochemical iron-cycle: a review. Biogeosciences 7, 827-844 (Iron biogeochemistry across marine systems at changing times).

Dulac, F., et al., 1996. Quantitative remote sensing of African dust transport to the Mediterranean. In: Guerzoni, S., Chester, R. (Eds.), The Impact of Desert Dust across the Mediterranean. Kluwer Academic Publishers, pp. 25-49.

Fierstein, J., Nathenson, M., 1992. Another look at the calculation of fallout tephra volumes. Bull. Volcanol. 54, 156-167.
Folch, A., Costa, A., Macedonio, G., 2009. FALL3D: a computational model for transport and deposition of volcanic ash. Comput. Geosci. 35, 1334-1342.

Frogner, P., Gislason, S.R., Óskarsson, N., 2001. Fertilizing potential of volcanic ash in ocean surface water. Geology 29, 487-490.

Garbe-Schönberg, C.D., 1993. Simultaneous determination of thirty-seven trace elements in twenty-eight international rock standards by ICP-MS. Geostand. Newslett. 17 (1), 81-97.

Guerzoni, S., et al., 1999. The role of atmospheric deposition in the biogeochemistry of the Mediterranean Sea. Prog. Oceanogr. 44, 147-190.

Guieu, C., Loÿe-Pilot, M.-D., Benyahya, L., Dufour, A., 2010. Spatial variability of atmospheric fluxes of metals ( $\mathrm{Al}, \mathrm{Fe}, \mathrm{Cd}, \mathrm{Zn}$ and $\mathrm{Pb}$ ) and phosphorus over the whole Mediterranean from a one-year monitoring experiment: biogeochemical implications. Mar. Chem. 120, 164-178.

Hamme, R.C., et al., 2010. Volcanic ash fuels anomalous plankton bloom in subarctic northeast Pacific. Geophys. Res. Lett. 37.

Heller, M.I., Croot, P.L., 2011. Superoxide decay as a probe for speciation changes during dust dissolution in Tropical Atlantic surface waters near Cape Verde. Mar. Chem. 126 (1-4), 37-55.

Herut, B., et al., 2005. Response of east Mediterranean surface water to Saharan dust: onboard microcosm experiment and field observations. Deep-Sea Res. II 52, 3024-3040.

Hoffmann, L., et al., 2012. Influence of volcanic ash and pumice on phytoplankton growth and $\mathrm{Cu}$ ligand production of Thalassiosira pseudonana and Emiliania huxleyi. Mar. Chem. 132-133, 28-33.

Jones, M.T., Gislason, S.R., 2008. Rapid releases of metal salts and nutrients following the deposition of volcanic ash into aqueous environments. Geochim. Cosmochim. Acta 72, 3661-3680.

Kelepertsis, A.E., Alexakis, D.E., Nastos, P.T., Kanellopoulou, E.A., 2003. The presence of volcanic ash in the western Greece and its association with the eruption of the Etna volcano, Italy. Consequences on the Environment, 8th International Conference on Environmental Science and Technology, Lemnos Island, Greece, pp. 408-415.

Krom, M.D., Kress, N., Brenner, S., Gordon, L.I., 1991. Phosphorus limitation of primary productivity in the eastern Mediterranean Sea. Limnol. Oceanogr. 36, 424-432.

Krom, M.D., et al., 2005. Nutrient cycling in the south east Levantine basin of the eastern Mediterranean: results from a phosphorus starved system. Deep-Sea Res. II 52, 2879-2896.

Kubilay, N., Nickovic, S., Moulin, C., Dulac, F., 2000. An illustration of the transport and deposition of mineral dust onto the eastern Mediterranean. Atmos. Environ. 34, 1293-1303.

Kutterolf, S., Freundt, A., Perez, W., 2008. Pacific offshore record of plinian arc volcanism in Central America: 2 tephra volumes and erupted masses. Geochem. Geophys. Geosyst. 9, 1-19.

Langmann, B., Zaksek, K., Hort, M., Duggen, S., 2010. Volcanic ash as fertiliser for the surface ocean. Atmos. Chem. Phys. 10, 3891-3899.

Leblanc, K., Qu'eguiner, B., Raimbault, P., Garcia, N., 2005. Efficiency of the silicate pump at a coastal oligotrophic site in the Mediterranean Sea. Biogeosci. Discuss. 2, 551-580.

Lin, I.I., et al., 2011. Fertilization potential of volcanic dust in the low-nutrient lowchlorophyll western North Pacific subtropical gyre: satellite evidence and laboratory study. Global Biogeochem. Cycles 25.

Markaki, Z., et al., 2003. Atmospheric deposition of inorganic phosphorus in the Levantine Basin, eastern Mediterranean: spatial and temporal variability and its role in seawater productivity. Limnol. Oceanogr. 48, 1557-1568.

Mihalopoulos, N., Stephanou, E., Kanakidou, M., Pilitsidis, S., Bousquet, P., 1997. Tropospheric aerosol ionic composition in the Eastern Mediterranean region. Tellus 49B, 314-326.

Mills, M.M., Ridame, C., Davey, M., La Roche, J., Geider, R., 2004. Iron and phosphorus colimit nitrogen fixation in the eastern tropical North Atlantic. Nature 429, 292-294.

Morel, F.M.M., Price, N.M., 2003. The biogeochemical cycles of trace metals in the oceans. Science 300 (5621), 944-947.

Moutin, T., Raimbault, P., 2002. Primary production, carbon export and nutrients availability in western and eastern Mediterranean Sea in early summer 1996 (MINOS cruise). J. Mar. Syst. 33-34, 273-288.

Moutin, T., et al., 2002. Does competition for nanomolar phosphate supply explain the predominance of the cyanobacterium Synechococcus? Limnol. Oceanogr. 47, 273-288.

Olgun, N., et al., 2011. Surface ocean iron fertilization: the role of airborne volcanic ash from subduction zone and hotspot volcanoes and related iron-fluxes into the Pacific Ocean. Global Biogeochem. Cycles 25.

Paytan, A., et al., 2009. Toxicity of atmospheric aerosols on marine phytoplankton. Proc. Natl. Acad. Sci. 106, 4601-4605.

Pulido-Villena, E., Rerolle, V., Guieu, C., 2010. Transient fertilizing effect of dust in P-deficient LNLC surface ocean. Geophys. Res. Lett. 37.

Pyle, D.M., 1989. The thickness, volume and grain size of tephra fall deposits. Bull. Volcanol. 51, 1-15.

Ridame, C., Guieu, C., 2002. Saharan input of phosphate to the oligotrophic water of the open western Mediterranean Sea. Limnol. Oceanogr. 47, 856-869.

Ridame, C., Moutin, T., Guieu, C., 2003. Does phosphate adsorption onto Saharan dust explain the unusual N/P ratio in the Mediterranean Sea? Oceanol. Acta 26, 629-634.

Ruiz-Pino, D.P., Nicolas, E., Bethoux, J.P., Lambert, C.E., 1991. Zinc budget in the Mediterranean Sea: a hypothesis for non-steady-state behavior. Mar. Chem. 33, 145-169.

Sarthou, G., Jeandel, C., 2001. Seasonal variations of iron concentrations in the Ligurian Sea and iron budget in the Western Mediterranean Sea. Mar. Chem. 74, 115-129.

Saydam, A.C. 1996. Can we predict harmful algae blooms. Harmful Algae News 15, 5-6.

Schiano, P., Clocchiatti, R., Ottolini, L., Busa, T., 2001. Transition of Mount Etna lavas from a mantle-plume to an island-arc magmatic source. Nature 412, 900-904.

Schink, D.R., Kingston, R.I., 1967. Budget for dissolved silica in the Mediterranean Sea. Geochim. Cosmochim. Acta 31, 987-999. 
Scollo, S., Carlo, P.D., Coltelli, M., 2007. Tephra fallout of 2001 Etna flank eruption: analysis of the deposit and plume dispersion. J. Volcanol. Geotherm. Res. 160, 147-164.

Sherrell, R.M., Boyle, E.A., 1988. Zinc, chromium, vanadium and iron in the Mediterranean Sea. Deep-Sea Res. 35, 1319-1334.

Socal, G., et al., 1999. Nutrient, particulate matter and phytoplankton variability in the photic layer of the Otranto strait. J. Mar. Syst. 20, 381-398.

Tanaka, T., et al., 2011. Lack of P-limitation of phytoplankton and heterotrophic prokaryotes in surface waters of three anticyclonic eddies in the stratified Mediterranean Sea. Biogeosciences 8, 525-538.

Ternon, E., et al., 2010. The impact of Saharan dust on the particulate export in the water column of the North Western Mediterranean Sea. Biogeosciences 7, 809-826.

Thingstad, T.F., Rassoulzadegan, F., 1995. Nutrient limitations, microbial food webs, and 'biological C-pumps': suggested interactions in a P-limited Mediterranean. Mar. Ecol. Prog. Ser. 117, 299-306.
Thingstad, T.F., Zweifel, U.L., Rassoulzadegan, F., 1998. P limitation of heterotrophic bacteria and phytoplankton in the northwest Mediterranean. Limnol. Oceanogr. 43, 88-94.

Uematsu, M., et al., 2004. Enhancement of primary productivity in the western North Pacific caused by the eruption of the Miyake-jima volcano. Geophys. Res. Lett. 31 (L06106), 1-4.

Wagener, T., Guieu, C., Leblond, N., 2010. Effects of dust deposition on iron cycle in the surface Mediterranean Sea: results from a mesocosm seeding experiment. Biogeosciences 7, 2799-2830.

Wiesner, M.G., Wang, Y., Zheng, L., 1995. Fallout of volcanic ash to the deep South China Sea induced by the 1991 eruption of Mount Pinatubo (Philippines). Geology 23 (10), 885-888. 